\title{
Construction Safety Plan pada Gedung Bertingkat berdasarkan Peraturan Menteri Pekerjaan Umum Nomor 05/PRT/M/2014
}

\author{
Hendra Alexander ${ }^{1}$, Rahmi Hidayat ${ }^{2}$, Merley Misriani ${ }^{3}$, Yurisman ${ }^{4}$, Willy Pangestu Haryanto \\ 1,2,3,4,5 Teknik Sipil Politeknik Negeri Padang \\ Email : hendraalexander@pnp.ac.id
}

\begin{abstract}
This research is motivated by the frequent occurrence of work accidents in construction projects during 2017-2018, this gives a meaning that there is still a lack of attention to aspects of occupational health and safety (OHS). Therefore a plan is made which, if implemented in a project, can minimize the occurrence of work accidents called the construction safety plan. The purpose of this research is to make a construction safety plan by identifying any risks that can cause work accidents in construction projects.

This research is based on direct observation methods on construction projects and literature studies related to risk and OHS. This research begins by identifying risks based on the Minister of Public Works Regulation PERMENPU NUMBER: 05 / PRT / M / 2014 where there will be hazards that can cause workplace accidents and how to control them, then a construction safety plan consisting of work safety policies, targets and work safety programs, and implementation of workplace safety activities in the field. The results of this study are that there are 36 risk variables that can cause work accidents, consisting of 7 variables with high risk, 21 variables with moderate risk and 8 variables with low risk. The targets made were the achievement of zero accidents with safety induction programs, safety precautions, safety talk, safety meetings, safety patrols and the use of personal protective equipment. Then the implementation plan of work safety in the field includes evacuation route planning, building protection planning, planning to work at height, etc.
\end{abstract}

Keywords: Occupational Safety planning, risk identification, goals and OHS programs.

\section{PENDAHULUAN}

Masalah keselamatan dan kesehatan kerja (K3) secara umum di Indonesia masihsering terabaikan. Hal ini ditunjukkan dengan masih tingginya angka kecelakaan kerja.Menteri TenagaKerja Hanif Dhakiri menjelaskan, berdasarkan data Badan Penyelenggara Jaminan Sosial (BPJS) Ketenagakerjaan, sepanjang tahun 2017, tercatat 1.877 klaim atau setara dengan nilai Rp 41,2 miliar untuk tenaga kerja konstruksi.Banyaknya kecelakaan kerja itu terjadi lantaran beberapa faktor. Di antaranya, kurang disiplinnya tenaga kerja dalam mematuhi aturan terkait dengan keselamatan, selain itu menilai pengawasan K3 di internal tempat kerja juga masih lemah.
Berikut beberapa contoh kecelakaan kerja pada gedung yang terjadi di tahun 2017 2018:

1. Jatuhnya tulangan pada proyek rusunawa Pasar Rumput,Jakarta Selatan yang menelan korban seorang penduduk sekitar, kejadian ini terjadi pada 18 Maret 2018. Penyebab dari kecelakaan ini adalah kesalahan dalam proses angkut tulangan dan kurangnya safety net.

2. Kecelakaan kerja pada proyek 78 Sudirman, Jakarta Pusat pada tanggal 16 Januari 2018 yang mengakibatkan meninggalnya seorang pekerja dikarenakan tertimpa oleh material yang jatuh. Penyebab dari kecelakaan ini adalah tidak adanya safety void. 
3. Robohnya podium pada proyek apartemen pakubowono, Kebayoran lama, Jakarta Selatan yang menelan korban sebanyak 3 orang pekerja, kejadian ini terjadi pada 17 Desember 2017. Penyebab kecelakaan kerja adalah tidak kuatnya dinding yang berfungsi sebagai penahan podium.

Sebagian besar, presentasi pembelajaran di perguruan tinggi adalah untuk menghasilkan bangunan (struktur) yang dapat menjamin keselamatan pemakai dalam jangka pendek maupun jangka panjang. Lalu bagaimana dengan proses pelaksanaan bangunan konstruksi itu sendiri? Bagaimana mendapatkan bahwa proyek berjalan dengan lancar tanpa ada atau timbul kecelakaan kerja, apalagi sampai jatuh korban jiwa? Oleh karena itu dibutuhkan suatu perencanaan yang dapat meminimalisir terjadinya kecelakaan kerja di proyek konstruksi menuju "zero accident" yang disebut dengan construction safety plan.

Objek penelitian ini adalah proyek SOUTHGATE Jakarta Selatan, penelitian ini dilakukan ketika melakukan praktek kerja lapangan (PKL) saat itu proyek ini merupakan pembangunan gedung bertingkat delapan lantai dengan tiga basement yang dibangun selama 35 bulan kalender di kawasan Jakarta Selatan. Proyek yang dilaksanakan mulai dari bulan Oktober tahun 2016 ini merupakan proyek konstruksi gedung yang cukup besar yang tentunya memiliki risiko pekerjaan yang besar pula terhadap personil maupun nonpersonil yang ada di area proyek.

\section{RUMUSAN MASALAH}

Sesuai dengan latar belakang di atas, makadiambil rumusan masalah sebagai berikut:

1. Identifikasi risiko yang terkait keselamatan kerja pada pelaksanaan upper structure proyek gedung bertingkat.

2. Construction safety plan untuk menghindari atau meminimalisir risiko kecelakaan kerja yang terjadi pada upper structureproyek gedung bertingkat.

\section{BATASAN MASALAH}

Batasan masalah pada penulisan ini yaitu perencanaan keselamatan kerja (Construction Safety Plan) pada pekerjaan upper structureproyek SOUTHGATE Jakarta Selatan.

\section{TUJUAN PENELITIAN}

Adapun tujuan penulisan yang ingin dicapai adalah :

1. Mengidentifikasi risiko terjadinya suatu kecelakaan kerja pada pekerjaan upper structure proyek konstruksigedung bertingkat.

2. Merencanakan suatu construction safety untuk upper structure gedung sebagai upaya untuk mengurangi dan mencegah terjadinya kecelakaan kerja pada proyek gedung bertingkat, sesuai dengan peraturan pemerintah Indonesia yang berlaku.

\section{MANFAAT PENELITIAN}

Manfaat yang hendak dicapai dalam penulisan ini, adalah :

1. Kontraktor berusaha mencegah kecelakaan yang dapat merugikan semua pihak yang berada di lokasi proyek termasuk masyarakat sekitar. 
2. Kontraktor berusaha membuat construction safety plan untuk menuju "zero accident".

3. Sosialisasi penerapan construction safety plan untuk proyek konstruksi gedung pada semua pihak yang terkait dengan proyek.

\section{TINJAUAN PUSTAKA}

\section{Keselamatan Kerja}

Keselamatan kerja merupakan hal yang sangat penting dalam melaksanakan suatu pekerjaan. Pekerjaan yang baik bukan hanya pekerjaan yang selesai tepat waktu dan menghasilkan mutu produk yang baik, tetapi juga harus untung dari segi biaya dan dilaksanakan dengan selamat dan sehat tanpa ada kecelakaan kerja

Menurut Bangun Wilson (2012)Keselamatan Kerja adalah perlindungan atas keamanan kerja yang dialami pekerja baik fisik maupun mental dalam lingkungan pekerjaan.

Slamet (2012) yang dikutip Dewi Ratna (2017) juga mendefinisikan tentang keselamatan kerja. Keselamatan kerja dapat diartikan sebagai keadaan terhindar dari bahaya selama melakukan pekerjaan. Dengan kata lain keselamatan kerja merupakan salah satu faktor yang harus dilakukan selama bekerja, karena tidak ada yang menginginkan terjadinya kecelakaan di dunia ini. Keselamatan kerja sangat bergantung .pada jenis, bentuk, dan lingkungan dimana pekerjaan itu dilaksanakan.

Menurut Malthis dan Jackson (2002) yang dikutip Ibrahim (2010), keselamatan kerja menunjukpada perlindungan kesejahteraan fisik dengan dengan tujuan mencegah terjadinya kecelakaan atau cedera terkait dengan pekerjaan. Pendapat lain menyebutkan bahwa keselamatan kerja berarti proses merencanakan dan mengendalikan situasi yang berpotensi menimbulkan kecelakaan kerja melalui persiapan prosedur operasi standar yang menjadi acuan dalam bekerja (Rika Ampuh Hadiguna, 2009).

Unsur-unsur penunjang keselamatan kerja adalah sebagai berikut:

1. Adanya unsur-unsur keamanan dan kesehatan kerja

2. Adanya kesadaran dalam menjaga keamanan dan kesehatan kerja

3. Teliti dalam bekerja

4. Melaksanakan prosedur kerja dengan memperhatikan keamanan dan kesehatan kerja.

\section{Kecelakaan Kerja Konstruksi}

Kecelakaan kerja adalah suatu kejadian yang tidak dikehendaki dan tidak diduga semula yang dapat menimbulkan korban jiwa dan harta benda (PermenakerNomor:03/Men/1998).

Berdasarkan UU No. 1 Tahun 1970 tentang keselamatan kerja, kecelakaan kerja adalah suatu kejadian yang tidak diduga semula dan tidak dikehendaki, yang mengacaukan proses yang telah diatur dari suatu aktivitas dan dapat menimbulkan kerugian baik korban manusia maupun harta benda.

Adapun klasifikasi kecelakaan kerja berdasarkan tingkat keparahannya yaitu (Ihsan, 2011):

a. Fatal/Meninggal :

Kecelakaan yang menyebabkan kematian tanpa memperhitungkan tenggang waktu antara terjadinya kecelakaan dengan meninggalnya korban.

b. Berat. 
Kecelakaan kerja berat yakni kecelakaan kerja yang mengalami amputasi dan kegagalan fungsi tubuh. Seperti patah tulang, cacat, hingga amputasi.

c. Sedang.

Kecelakaan kerja sedang yaitu kecelakaan yang membutuhkan pengobatan dan perlu istiraha selama lebih dari 2 hari. Seperti terjepit, luka sampai robek, luka bakar..

d. Ringan.

Kecelakaan kerja ringan merupakan kecelakana yang membutuhkan pengobatan di hari itu dan dapat melakukan pekerjaannya kembali atau istirahat kurang dari 2 hari. Seperti terpeleset, tergores, terkna pecahan beling, terjatuh dan terkilir.

\section{Risiko Pada Proyek Konstruksi}

Dalam dunia nyata selalu terjadi perubahan yang sifatnya dinamis, sehingga selalu terdapat ketidakpastian. Risiko timbul karena adanya ketidakpastian, dan risikoakan menimbulkan konsekuensi tidak menguntungkan. Jika risiko tersebut menimpasuatu proyek, maka proyek tersebut bisa mengalami kerugian yang signifikan. Dalam beberapa situasi, risiko tersebut bisa mengakibatkan terbengkalainya proyek tersebut.( Yuliani;2016 )

Risiko-risiko yang terdapat pada proyek konstruksi sangat banyak, namun tidak semua perlu diprediksi dan diperhatikan untuk memulai suatu proyek karena hal ituakan memakan waktu yang lama. Olehkarena itu pihak-pihak didalam proyek kontruksi perlu untuk memberi prioritas pada risiko-risiko yang penting yangakan memberikan pengaruh terhadap keuntungan proyek
Berdasarkan berbagai definisi risiko yang telah dijelaskan dapat disimpulkan bahwa risiko merupakan ukuran kemungkinan (probability) dengan besarnya dampak (qonsequence) dari suatu keadaan yang dapat menimbulkan kecelakaan. Untuk dapat mengenali risiko terlebih dahulu harus diperoleh pemahaman mengenai apa saja yang ada dalam risiko itu sendiri.

\section{Identifikasi Risiko}

Penilaian risiko dapat dilakukan dengan terlebih dahulu melakukan identifikasi risiko. Identifikasi risiko adalah tahapan yang sangat kritikal dalam proses penilaian risiko yaitu merekam semua risiko baik yang sudah maupun belum dikendalikan melalui pengendalian inten. Proses yang dilakukan dalam tahap identifikasi risiko adalah:

1. Menginventarisasi data kejadian/peristiwa komprehensif yang mempengaruhi organisasi

2. Menentukan sumber-sumber risiko, antara lain hubungan bisnis dan hukum, lingkungan ekonomi, perilaku manusia, kejadian alam, lingkungan politik, isu teknologi, aktivitas manajemen dan aktivitas individu.

3. Menentukan area yang terkena pengaruh risiko, antara lain aset dan sumber daya, pendapatan, biaya, pegawai, masyarakat, kinerja, waktu dan jadual aktivitas, lingkungan.

Menentukan penyebab dan skenario risiko.

Form identifikasi risiko yang akan digunakan merujuk pada PermenPU No 5 tahun 2014, dimana form nya berbentuk sebagai berikut: 
Tabel 1 : Form identifikasi risiko

Sumber : PermenPU No 52014

\begin{tabular}{|c|c|c|c|c|c|c|c|c|}
\hline \multirow[b]{2}{*}{ No } & \multirow[b]{2}{*}{$\begin{array}{l}\text { URAIAN } \\
\text { PEKERJALY }\end{array}$} & \multirow[b]{2}{*}{$\begin{array}{c}\text { IDENIFIIKASI } \\
\text { BAHAYA }\end{array}$} & \multicolumn{3}{|c|}{ PENILAIAN RISIKO } & \multirow[b]{2}{*}{$\begin{array}{l}\text { SKALA } \\
\text { PRIORITAS }\end{array}$} & \multirow[b]{2}{*}{$\begin{array}{l}\text { PENGENDALIAN } \\
\text { RISIKO K3 }\end{array}$} & \multirow{2}{*}{$\begin{array}{l}\text { PENANGGUNG } \\
\text { JaWAB } \\
\text { (Nama Petugas) }\end{array}$} \\
\hline & & & $\begin{array}{c}\text { KEKERAP } \\
\text { AN }\end{array}$ & $\begin{array}{c}\text { KEPARAH } \\
\text { AN }\end{array}$ & $\begin{array}{l}\text { TINGKAT } \\
\text { RISIKO }\end{array}$ & & & \\
\hline (1) & (2) & (3) & $(4)$ & (5) & (6) & (7) & (81) & (9) \\
\hline 1 & $\begin{array}{l}\text { Pelkerjaan } \\
\text { galian pada } \\
\text { basement } \\
\text { bangunan } \\
\text { getung } \\
\text { dengan } \\
\text { kondisi tanah } \\
\text { labil }\end{array}$ & Tertimbun & 3 & 3 & $\stackrel{9}{9}$ & 1 & 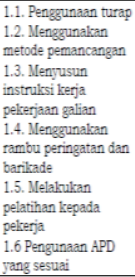 & $\begin{array}{l}\text { Pengaras lapangan/ } / \\
\text { quality engineer }\end{array}$ \\
\hline
\end{tabular}

Pengisian Tabel 1:

1. Kolom(1):Nomor urut uraian pekerjaan.

2. Kolom(2): Diisi seluruh item pekerjaan yang mempunyairisiko K3 yang tertuang di dalam dokumenpelelangan.

3. Kolom(3): Diisi dengan identifikasi bahaya yang akantimbul dari seluruh item pekerjaan yangmempunyai risiko $\mathrm{K} 3$.

4. Kolom(4): Diisi dengan nilai (angka) kekerapan terjadinyakecelakaan.

Tabel 2 : nilai kekerapan terjadinya kecelakaan kerja

\begin{tabular}{|l|l|}
\hline Nilai & \multicolumn{1}{|c|}{ Kekerapan } \\
\hline 1 & $\begin{array}{l}\text { Jarang terjadi dalam } \\
\text { kegiatan konstruksi }\end{array}$ \\
\hline 2 & $\begin{array}{l}\text { Kadang-kadang terjadi } \\
\text { dalam kegiatan konstruksi }\end{array}$ \\
\hline 3 & $\begin{array}{l}\text { Sering terjadi dalam } \\
\text { kegiatan konstruksi }\end{array}$ \\
\hline
\end{tabular}

Sumber: Permen PU no 5 tahun 2014

5. Kolom(5): Diisi dengan nilai (angka) keparahan.

Tabel 3 Nilai keparahan kecelakaan kerja

\begin{tabular}{|l|l|}
\hline Nilai & Tingkat \\
\hline 1 & Ringan \\
\hline
\end{tabular}

\begin{tabular}{|l|l|}
\hline 2 & Sedang \\
\hline 3 & Berat \\
\hline
\end{tabular}

Sumber: Permen PU no 5 tahun 2014

6. Kolom (6): Perhitungan tingkat risiko $\mathrm{K} 3$ adalah nilai kekerapan $\mathrm{x}$ keparahan.

Tabel 4 Perhitungan tingkat risiko

\begin{tabular}{|c|c|c|c|c|}
\hline \multirow{2}{*}{\multicolumn{2}{|c|}{$\begin{array}{c}\text { TINGKAT RISIKO K3 } \\
\text { KONSTRUKSI }\end{array}$}} & \multicolumn{3}{|c|}{ Keparahan (Akibat) } \\
\hline & & 1 & 2 & \multirow{2}{*}{$\begin{array}{l}3 \\
3\end{array}$} \\
\hline \multirow[t]{3}{*}{ Kekerapan } & 1 & & 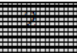 & \\
\hline & 2 & \# & 4 & 6 \\
\hline & 3 & 3 & 6 & 9 \\
\hline
\end{tabular}

Keterangan:

:Tingkat Risiko K3 Rendah;

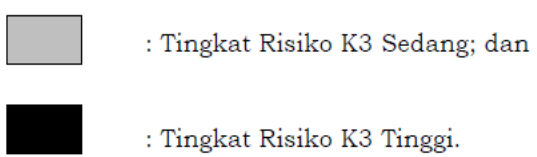

Sumber: Permen PU no 5 tahun 2014

7. Kolom (7): Penetapan skala prioritas ditetapkanberdasarkan item pekerjaan yang mempunyaitingkat risiko K3 tinggi, sedang dan kecil,dengan penjelasan: prioritas 1 (risiko tinggi),prioritas 2 (risiko sedang), dan prioritas 3 (risikokecil). Apabila tingkat risiko dinyatakan tinggi,maka item pekerjaan tersebut menjadi prioritasutama (peringkat 1) dalam upaya pengendalian.

Kolom (8): Diisi bentuk pengendalian risiko K3.

\section{METODOLOGI PENELITIAN}

Metodologi dalam penelitian inidimulai dengan tahap pengumpulan data, tahap pengolahan data, dan tahap analisis. Berikut merupakan flowchart metodologi penelitian ini: 


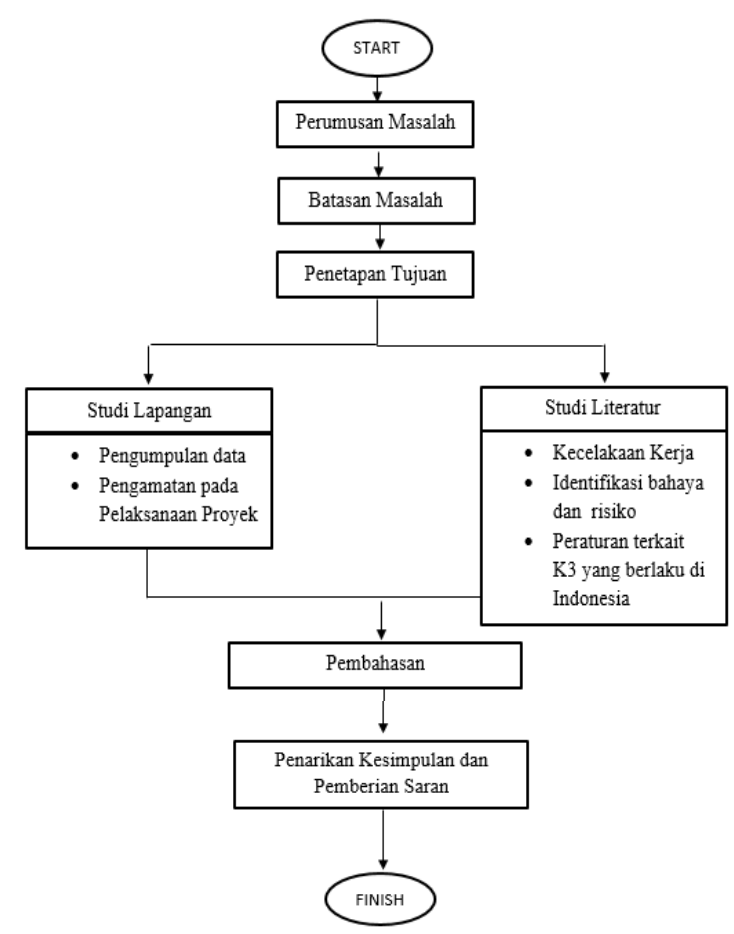

\section{ANALISA DAN PEMBAHASAN}

\section{Safety plan}

Safety plan merupakan sebuah dokumen yang teridiri dari rencana keselamatan praktis yang dapat membantu perusahaan dalam menghindari potensi bahaya dan dapat mengendalikannya dengan cara yang terbaik ketika dalam kondisi berbahaya tersebut. Safety Plan sering digunakan oleh Pengguna Jasa / Owner sebagai salah satu persyaratan dalam tender. Berikut hal-hal yang disusun dalam safety plan:

\section{Kebijakan K3}

2. Identifikasi risiko, penilaian risiko, dan pengendalian risiko

\section{Sasaran dan program}

4. Implementasi K3 di lapangan.

\section{Kebijakan K3}

Berdasarkan penelitian untuk menghindari kecelakaan kerja serta untuk mencapai pekerjaan dengan zero accident maka dibuatlah kebijakan K3, sebagai berikut

1. Memastikan tidak terjadi kecelakaan kerja yang mengakibatkan kematian, waktu kerja hilang, perawatan medis, dan kejadian hampir celaka.

2. Menekan serta mengurangi potensi bahaya baik untuk situasi kerja yang membahayakan serta perilaku kerja yang tidak aman.

3. Mensosialisasikan serta membudayakan kebijakan keselamatan peru-sahaan bagi seluruh karyawan dan staff.

4. Menciptakan lingkungan kerja yang aman, selamat, tertib, bersih dan ramah lingkungan.

\section{Risk Assesment (Identifikasi Risiko)}

Pada proses identifikasi risiko ini hal-hal yang akan dibahas yaitu identifikasi bahaya, penilaian risiko serta pengendalian risiko. Beberapa item yang disebutkan didapat dari proses pengamatan pada lokasi penelitian dengan format mengacu pada Permen PU no.5 tahun 2014 tentang pedoman sistem manajemen keselamatan dan kesehatan kerja (SMK3) konstruksi bidang pekerjaan umum.

Adapun identifikasi resiko dilaksanakan pada tahapan pekerjaan :

1. Tahapan persiapan.

2. Tahapan pekerjaan pabrikasi besi dan bekisting.

3. Tahapan pekerjaan instalasi pekerjaan tower crane dan penggunaannya.

4. Tahapan pekerjaan plat lantai dan balok.

5. Tahapan pekerjaan beton yang vertikal.

Berikut adalah hasil dari identifikasi risiko yang dilakukan selama penelitian: 


\begin{tabular}{|c|c|c|}
\hline No & Tingkat penilaian risiko & Jumlah \\
\hline 1 & 1 & 3 \\
\hline 2 & 2 & 5 \\
\hline 3 & 3 & 10 \\
\hline 4 & 4 & 11 \\
\hline 5 & 6 & 5 \\
\hline 6 & 9 & 2 \\
\hline
\end{tabular}

\section{Sasaran K3}

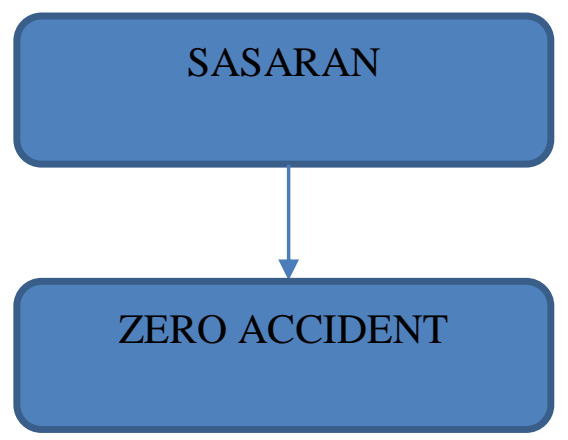

\section{Gambar 1: Sasaran K3}

Sasaran pada penyusunan safety plan ini adalah tercapainya zero accident selama proyek berlangsung yang didukung oleh program K3. Walaupun dalam penerapannya tidak tercapai zero accident setidaknya program yang disusun sudah mendekati sasaran dan menuju zero accident.

\section{Program K3}

Program K3 dibuat sebagai perlindungan bagi pekerja agar dapat terlepas dari bahaya kecelakaan akibat kerja, selain itu program ini juga bertujuan untuk membuat suasana kerja menjadi aman dan nyaman sehingga pekerja dapat bekerja lebih produktif. Programprogram K3 yang dapat digunakan untuk mengontrol pekerjaan di lapangan berdasarkan penelitian yang telah dilakukan meliputi kegiatan-kegiatan:
1. Safety Induction

2. Safety Inspection

3. Safety Talk

4. Safety Monitoring

5. Safety Meeting

6. Safety Patrol

7. Alat Pelindung Diri (APD)

\section{Implementasi K3 di lapangan}

Berikut aturan serta motode yang dapat menunjang keselamatan kerja pekerja di lapangan :

1. Jalur evakuasi

2. Proteksi gedung

3. Bekerja di ketinggian

4. Bekerja yang berhubungan dengan Isitrik

5. Pemotongan dan pengelasan

6. Safety Void

7. Pencegahan kebakaran

8. Bekerja dengan Tower Crane (TC)

9. Rambu-rambu dan slogan K3

10. Rencana tanggap darurat.

Construction safety plan adalah suatu perencanaan $\mathrm{K} 3$ yang disusun untuk meminimalisir terjadinya kecelakaan kerja untuk menuju zero accident pada proyek. Construction safety plan ini dimulai dengan identifikasi risiko dari bahaya yang dapat menyebabkan kecelakaan kerja kemudian risiko tersebut dilakukan pengendalian dengan menyusun program-program dan implementasi K3 di lapangan. Jalannya program serta implementasi K3 di lapangan sangat bergantung kepada personil pengawas/supervisor K3, dikarenakan supervisor K3 inilah yang menegakkan dan mengawasi jalannya safety plan di lapangan. Oleh karena itu untuk menuju zero accident dibutuhkan safety plan yang baik dan 
supervisor K3 yang bersertifikat atau kompeten.

\section{PENUTUP}

\section{Kesimpulan}

Berdasarkan penelitian yang dilakukan di proyek SOUTHGATE, Jakarta Selatan yang berjudul "Perencanaan Construction Safety pada Gedung Bertingkat" dan telah dilakukan pembahasan serta analisa terhadap data yang didapatkan maka dapat ditarik kesimpulan sebagai berikut :

1. Penyusunan construction safety plan dimulai dengan mengidentifikasi risiko pekerjaan yang dapat menyebabkan kecelakaan kerja. Hasil dari identifikasi risiko pekerjaan yang dilakukan berdasarkan PermenPU no.5 tahun 2014 didapatkan hasil, yaitu:

a. Terdapat 7 variabel risiko penyebab kecelakaan kerja yang mempunyai tingkat risiko tinggi dengan penilaian 6 dan 9

b. Untuk risiko sedang didapatkan 21 variabel risiko dengan nilai 3 dan 4 .

c. Risiko rendah didapatkan 8 variabel risiko dengan nilai 1 dan 2.

2. Penyusunan construction safety plan untuk meminimalisir risiko yang terjadi sehingga dapat menuju zero accident yaitu dengan membuat kebijakan K3, pengendalian risiko, sasaran dan program serta implementasi kegiatan K3 di lapangan.

Saran.

Saran yang dapat diberikan berdasarkan penelitian yang telah dilakukan adalah

1. Untuk menyusun construction safety plan yang baik kontraktor harus membuat sebuah identifikasi risiko secara menyeluruh dengan kecelakaan yang sudah terjadi sebagai bahan pembelajaran.

2. Jika kontraktor ingin mencegah kecelakaan kerja sehingga dapat menuju zero accident, maka kontraktor harus menyusun safety plan yang baik. Untuk penerapan di lapangan harus dengan sungguh-sungguh seperti menempatkan supervisor K3 yang berkompeten dan besertifikat untuk mengawasi jalannya safety plan sesuai dengan rencana.

\section{DAFTAR PUSTAKA}

Ario Raja, Sumargo dkk,2006. Keruntuhan Perancah ScaffoldingSaat Pelaksanaan Pengecoran

Ayuma Ersamayori Milen, 2016. Analisis Level Keselamatan Dan KesehatanKerja (K3) Proyek Konstruksi Terhadap RisikoDan Manajemen K3(Studi Kasus : Proyek Pembangunan Terminal li Bandara Radin Inten li, GedungParkir Bandara Radin Inten li Dan Showroom Auto 2000 Soekarno-Hatta)

Bobby Rocky Kani, 2013. Keselamatan Dan Kesehatan Kerja Pada Pelaksanaan Proyek Konstruksi (Studi Kasus: Proyek Pt. Trakindo Utama).

Dameyanti Sihombing, 2014. Implementasi Keselamatan Dan Kesehatan Kerja (K3)Pada Proyek Di Kota Bitung(Studi Kasus Proyek Pembangunan Pabrik Minyak Pt.Mns)

Dian Arumningsih,2013. Perencanaan Keselamatan Dan Kesehatan Kerja Pada Pekerjaan Konstruksi Rehabilitasi Waduk Botok Kabupaten Sragen. 
Edo Wijanarko, 2017. Analisis Risiko Keselamatan Pengunjung Terminal Purabaya Menggunakan Metode Hirarc (Hazard Identification, Risk Assessment And Risk Control)

Endang Mulyani, Lusiana 2014. Perencanaan Sistem Keselamatan Dan Kesehatan Kerja (K3) Pada Proyek Pembangunan Perluasan Hotel Mercure 8 Lantai Kota Pontianak U. Hizra Ryan Fietra,

Gabby E. M. Soputan, 2014. Manajemen RisikoKesehatan Dan Keselamatan Kerja (K3) (Study Kasus Pada Pembangunan Gedung Sma Eben Haezar)

I Nyoman Astina, 2015. Value Engineering Antara Perancah Konvensional DenganScalfolding Pada Proyek Kontruksi (Studi Kasus Pada Gedung Bertingkat Di Smpn 10 Denpasar Bali)

Kemala Dewi Ratna,2017. Pengaruh Keselamatan Dan Kesehatan Kerja Terhadap Kinerja Karyawan Mhe Maintenance Department Badak Ngl Di Bontang

Labombang, Mastura 2011.Manajemen Risiko Dalam Proyek Konstruksi

Peraturan Menteri Pekerjaan Umum.2014. UndangUndang No 5 tahun 2014 tentang Pedoman Sistem Manajemen Keselamatan Dan Kesehatan Kerja(Smk3) Konstruksi Bidang Pekerjaan Umum. Seketariat Negara. Jakarta Peraturan Menteri Tenaga Kerja dan Transmigrasi Republik Indonesia. Undang-undang No. 9 Tahun 2010 tentang operator dan petugas pesawat angkat dan angkut. Seketariat Negara. Jakarta

Ramli, Soehatman. 2010 Sistem Manajemen Keselamatan \& Kesehatan Kerja. Ohsas 18001. Dian Rakyat, Jakarta :

Yuliani Christin, 2016. Evaluasi Risiko Teknis Pelaksanaan Struktur Atas Berdasarkan
Konsep Severity Index Risiko (Studi Kasus

Proyek Gedung P1-P2 Universitas KristenPetra Surabaya) . 